УДК 556.314(1-924.16)

\title{
ОСОБЕННОСТИ ВЗАИМОДЕЙСТВИЯ В СИСТЕМЕ ВОДА-ПОРОДА НА ТЕРРИТОРИИ ВОДОСБОРА ОЗЕРА ИМАНДРА (КОЛЬСКИЙ ПОЛУОСТРОВ)
}

\author{
Гусева Наталья Владимировна 1 , \\ gusevanv@tpu.ru
}

\author{
Воробьёва Дарья Андреевна ${ }^{1}$, \\ vorobeyda18@gmail.com
}

\author{
Евтюгина Зинаида Анатольевна2,3, \\ zina_evt@mail.ru \\ 1 Национальный исследовательский Томский политехнический университет, \\ Россия, 635050, г. Томск, пр. Ленина, 30. \\ 2 Апатитский филиал Мурманского государственного технического университета, \\ Россия, 184209, г. Апатиты, ул. Ферсмана, 50а. \\ 3 Кольский филиал ФИЦ «Единая геофизическая служба Российской академии наук», \\ Россия, 184209, г. Апатиты. ул. Ферсмана, 14.
}

\begin{abstract}
Актуальность исследования обусловлена тем, что при оценке эколого-геохимического состояния природной среды необходимо учитьвать соотношение природных и техногенных процессов, протекающих во всех ее компонентах (почве, воде, воздухе и т. д.). Так, основным природным процессом, определяющим обогащение вод химическими элементами, является их взаимодействие с горными породами. Однако на процессы в системе вода-порода значительное влияние может оказывать техногенный фрактор. В этой связи глубокое понимание особенностей гидрогеохимических процессов в пределах территорий, подверженных значительному техногенному воздействию, является важной задачей современной экогеохимии.

Цель: исследование особенностей взаимодействия вод с горными породами в условиях техногенной трансформации природной среды района озера Имандра Кольского полуострова.

объекты: подземные и поверхностные воды водосбора озера Имандра (Кольский полуостров).

Методы. Макрокомпонентный состав вод определялся методами ионной хроматографии, титриметрии, пламенной фотометрии, потенциометрии, фотоколориметрии, турбидиметрии. Для определения микрокомпонентов в составе вод использовался масс-спектрометр с индуктивно-связанной плазмой NexION 300D. Насыщенность вод к вторичной минеральной фразе оценивалась по величине индекса насыщения (SI), рассчитанной с помощью программного продукта PHREEQC.

Результаты. Установлено, что в пределах водосборной территории озера Имандра распространены низко минерализованные природные воды преимущественно гидрокарбонатного кальциевого состава с нейтральной и слабощелочной средой. Специфика химического состава вод западной и восточной частей рассматриваемой территории определяется совокупным влиянием природных и антропогенных фракторов. Так техногенное влияние комбината "Североникель» подтверждают повышенные концентрации никеля и меди в поверхностных водах западной части территории. Рассмотренные природные воды неравновесны с первичными алюмосиликатными минералами и насыщены гидроксидами, оксидами железа и алюминия и, в меньшей степени, меди, каолинитом, и, в отдельных точках, иллитом, Са- и Mg-монтмориллонитом. С позиций эволюционного развития высокая интенсивность водообмена на рассматриваемой территории является фактором, обусловливающим нахождения системы вода-порода на начальных стадиях. Наличие в составе равновесной минеральной фразы оксидов и гидроксидов меди свидетельствует о влиянии техногенных факторов на процессы взаимодействия в системе вода-порода.
\end{abstract}

\section{Ключевые слова:}

Гидрогеохимические условия, химический состав, природные воды, родник, озеро Имандра, Кольский полуостров, равновесие вод, насыщение вод, индекс насыщения.

\section{Введение}

Формирование химического состава вод происходит под влиянием как природных, так и антропогенных факторов [1-4]. Оценивая состояние вод, необходимо обосновать соотношение природных и техногенных источников веществ [5-7]. Рядом работ [8, 9] показано, что основным природным процессом, определяющим формирование химического состава вод, является взаимодействие их с горными породами. Формируя с горными породами единую систему, воды непрерывно растворяют минералы и обогащаются химическими элементами, при этом процесс этот носит эволюционный характер и на каждом этапе своего развития система вода-порода характеризуется своей спецификой $[10,11]$. На началь- ных стадиях взаимодействия с горными породами воды характеризуются максимальной агрессивностью, что сопровождается интенсивным переходом химических элементов в раствор. На этих этапах отсутствуют геохимические барьеры, лимитирующие накопление основных солеобразующих компонентов в растворе. Однако насыщенность вод к оксидам и гидроксидам и активное развитие сорбционных процессов сопровождаются выводом из раствора некоторых микрокомпонентов. Этот факт является весьма важным при оценке экологогеохимического состояния природных вод в районах активной хозяйственной деятельности, особенно в зоне влияния предприятий горнодобывающего и металлургического сектора. 
Район озера Имандра Кольского полуострова является территорией, где сконцентрированы крупные горнодобывающие и металлургические предприятия. Многолетнее воздействие выбросов никеля, меди и соединений серы Кольской горно-металлургической компании (КГМК) (площадка Мончегорск) привело к деградации лесных ландшафтов, вплоть до полного их разрушения и возникновения техногенных пустошей $[12,13]$, что, в свою очередь, также отразилось на особенностях гидрогеохимических условий.

\section{Объект и методы исследования}

В основу работы положены материалы гидрогеохимических исследований, проведенных в окрестностях озера Имандра (Кольский полуостров) в летнюю межень 2014 и 2016 гг. За весь период исследований было отобрано 37 проб подземных (родниковых) и поверхностных вод из 22 пунктов (рис. 1). В геомор- фологическом отношении район исследования приурочен к предгорьям Хибинского массива (восточная часть водосбора озера Имандра) и холмистоувалистой равнине (западная часть водосбора озера Имандра), в большей степени подвергшейся влиянию пылегазовых выбросов медно-никелевого комбината, что привело к формированию участка техногенной пустоши (рис. 1).

В геологическом отношении район исследования располагается в пределах восточной части Балтийского щита, сложенного породами кристаллического фундамента, перекрытыми рыхлыми четвертичными отложениями. На севере и северо-востоке территории водосбора озера Имандра распространены породы архейской эры: гранодиориты, тоналиты, плагиограниты, локально присутствуют гнейсы и амфиболиты с железистыми кварцитами.

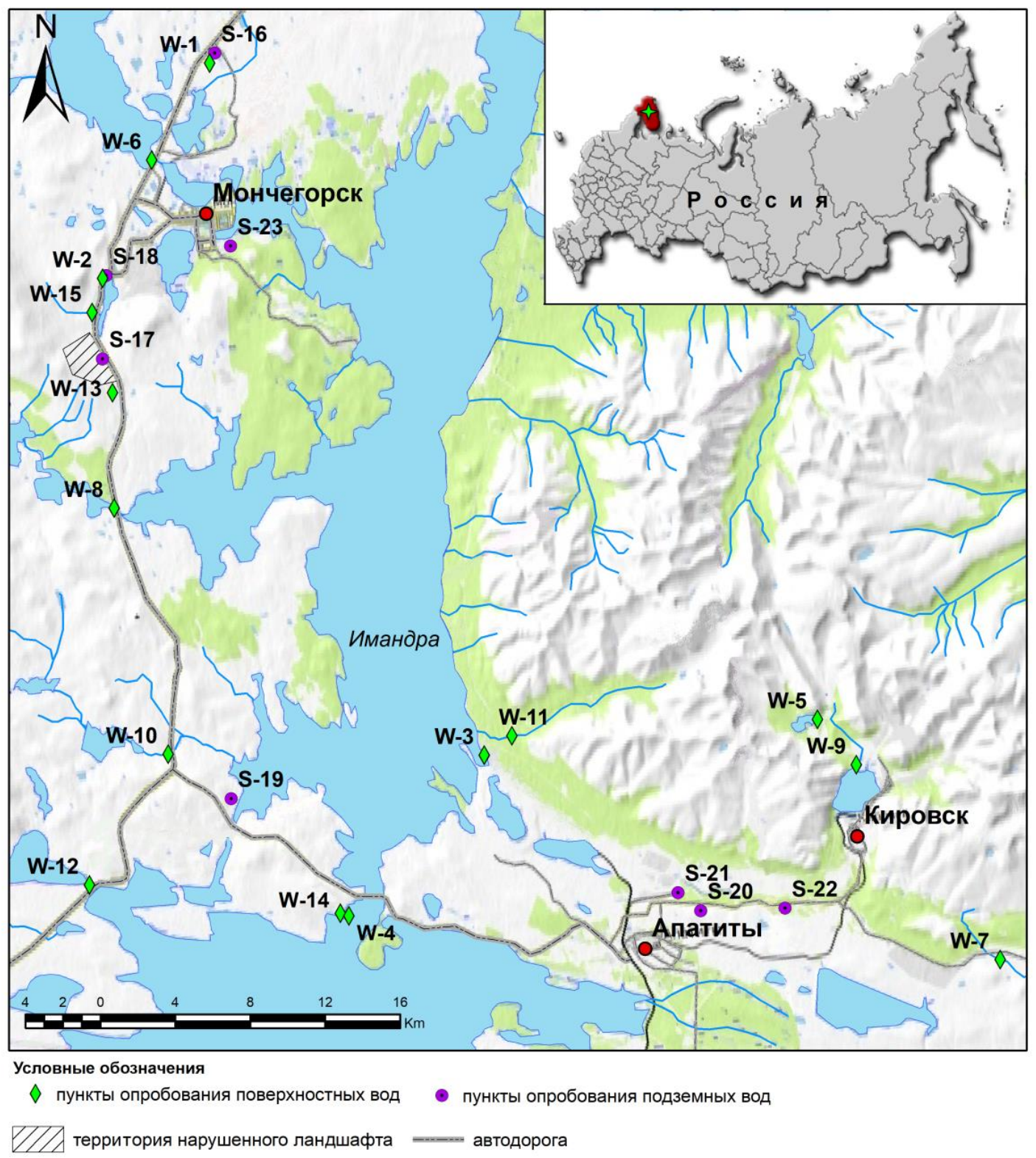

Рис. 1. Карта-схема пунктов гидрогеохимического опробования

Fig. 1. Map of the studied area and hydrogeochemical sampling points 
Восточную часть водосбора озера Имандра занимает Хибинский массив, сложенный щелочными ультрамафитами, нефелиновыми сиенитами, карбонатитами девонского периода. На юге рассматриваемой территории распространены биотитовые, амфиболпироксеновые гнейсы, мигматиты, тоналито-гнейсы, гранодиорито-гнейсы, амфиболиты. В западной части распространены разнообразные по возрасту и составу породы. Верхний архей на западном берегу представлен метавулканитами кислого и основного состава. Породы раннего протерозоя представлены перидотитами, пироксенами, габброноритами, базальтовыми порфиритами, норитами, диоритами, пероксенитами. Кроме того, локально встречаются отложения венда, сложенные аркозитовыми и полимиктовыми песчаниками, алевролитами, аргиллитами [14].

Изученные подземные воды преимущественно приурочены к зоне трещиноватости кристаллических пород, а также к четвертичным флювиогляциальным и озерно-ледниковым отложениям. Питание подземных вод осуществляется за счет инфильтрации атмосферных осадков [15].

Анализ химического состава вод проводился в проблемной научно-исследовательской лаборатории гидрогеохимии Томского политехнического университета. Макрокомпонентный состав вод был определен с использованием следующих аналитических методов: ионная хроматография, титриметрия, пламенная фотометрия, потенциометрия, фотоколориметрия, турбидиметрия. Для определения микрокомпонентов в составе вод использовался масс-спектрометр с индуктивно-связанной плазмой NexION 300D.

Степень насыщенности вод вторичными минеральными продуктами: оксидами, гидроксидами, глинами, гидрослюдой, кальцитом, гипсом, оценивалась по величине индекса насыщения (SI), который рассчитывался при помощи программы PHREEQC, а также посредством построения диаграмм полей устойчивости минералов. Отрицательное значение индекса насыщения говорит о ненасыщенности вод вторичными минералами, а положительные - o пересыщении.

\section{Результаты и их обсуждение}

Химический состав вод. Особенностью подземных вод рассматриваемого района является крайне низкая минерализация, при этом ее величина варьирует в весьма широких пределах - от 31 до 201 мг/дм ${ }^{3}$, что с учетом приуроченности выходов подземных вод к разным геоморфологическим формам предопределяет необходимость их анализа отдельно. Подземные воды предгорья Хибин характеризуются максимальной минерализацией $111-201 \quad \mathrm{M \Gamma} /$ дм $^{3}$ и являются нейтральными гидрокарбонатными кальциевыми (рис. 2). Концентрация кремния в водах изменяется в пределах 4,1-6,2 мг/дм ${ }^{3}$ и в среднем составляет $5,5 \mathrm{mг} /$ дм $^{3}$. Максимальная величина минерализации среди всех рассматриваемых вод - $201 \mathrm{мг} /$ дм $^{3}$ - отмечается в роднике Поддорожный (S-21), который находится на территории промышленной площадки второй апатит-нефелиновой обогатительной фабрики
(АНОФ-2), воды родника являются слабощелочными сульфатно-гидрокарбонатными натриевыми. Здесь же обнаружен нитрат-ион в количестве $33 \mathrm{мг} /$ дм$^{3}$, а железо и фтор содержатся в максимальных концентрациях среди всех рассматриваемых подземных вод 37,6 и 0,55 мг/дм ${ }^{3}$ соответственно. Остальные родники не проявляют признаки значительного загрязнения, отмечаются лишь повышенные концентрации калия $\left(5,1 \mathrm{мг} /\right.$ дм $\left.^{3}\right)$ и нитрат-иона $\left(2 \mathrm{мг} /\right.$ дм $\left.^{3}\right)$ в роднике Прихибинский (S-22), а также хлорид-иона (10,3 мг/дм $\left.{ }^{3}\right)$ в роднике Молодежный (S-20).

Минерализация подземных вод, приуроченных к холмисто-увалистой равнине, значительно ниже и составляет от 31 до $82 \mathrm{мг} /$ дм $^{3}$. Величина $\mathrm{pH}$ изменяется от 5,96 до 7,07. Концентрация кремния в водах варьируется от 3,7 до 9,6 мг/дм ${ }^{3}$ и в среднем составляет $6,22 \mathrm{мг} /$ дм$^{3}$.

При этом в родниках Кислая губа (S-19) и Спортивный (S-23) разгружаются нейтральные, преимущественно гидрокарбонатные, магниево-кальциевые подземные воды с минерализацией 67-82 мг/дм ${ }^{3}$ и содержанием сульфат-иона 7,6-11,1 мг/дм ${ }^{3}$. Содержание кремния в водах родников Спортивный (S-23) и Болотный (S-16) равнинной части исследуемого водосбора значительно превышает концентрацию основных катионов и составляет 8,4-9,6 мг/дм ${ }^{3}$ (табл. 1).

В родниках, расположенных в зоне воздействия выбросов комбината Североникель (S-18 и S-17) на юго-восточном склоне горы Мончетундра, происходит некоторая трансформация анионного состава, и воды становятся гидрокарбонатно-сульфатными родник Дорожный (S-18), и сульфатногидрокарбонатными - родник Горный (S-17), что сопровождается относительным снижением минерализации до 31-37 мг/дм ${ }^{3}$ при содержаниях сульфат-иона $8-13$ мг/дм ${ }^{3}$ и концентрацией кремния $3,7-4,5$ мг/дм ${ }^{3}$.

В родниках Горный (S-17), Дорожный (S-18) Кислая губа (S-19) наблюдается снижение $\mathrm{pH}(6,54$ и 5,96 соответственно) и увеличение концентраций свободной углекислоты до 9,1 и 17,4 мг/дм ${ }^{3}$. Повышенные концентрации свободной углекислоты в водах, возможно, связаны с процессами минерализации органического вещества. Вместе с тем снижение концентраций кремния в водах этих родников может быть обусловлено разубоживанием подземных вод атмосферными осадками или поверхностными водами.

Минерализация и величина $\mathrm{pH}$ поверхностных вод района исследования несколько ниже, чем подземных и составляют в среднем 28,5 мг/дм ${ }^{3}$ и 6,8 соответственно.

В нейтральных гидрокарбонатных поверхностных водах района Хибин (оз. Малый Вудъяр W-5; p. Айкуайвенйок W-7; p. Вудьяврйок W- 9; р. Малая Белая W-11) прослеживается преобладание натрия и калия над кальцием и особенно магнием при минерализации в среднем 27 мг/дм ${ }^{3}$ и содержании кремния 3,4 мг/дм ${ }^{3}$, что обусловлено влиянием распространенных здесь щелочных пород богатых калием и натрием $[16,17]$. 


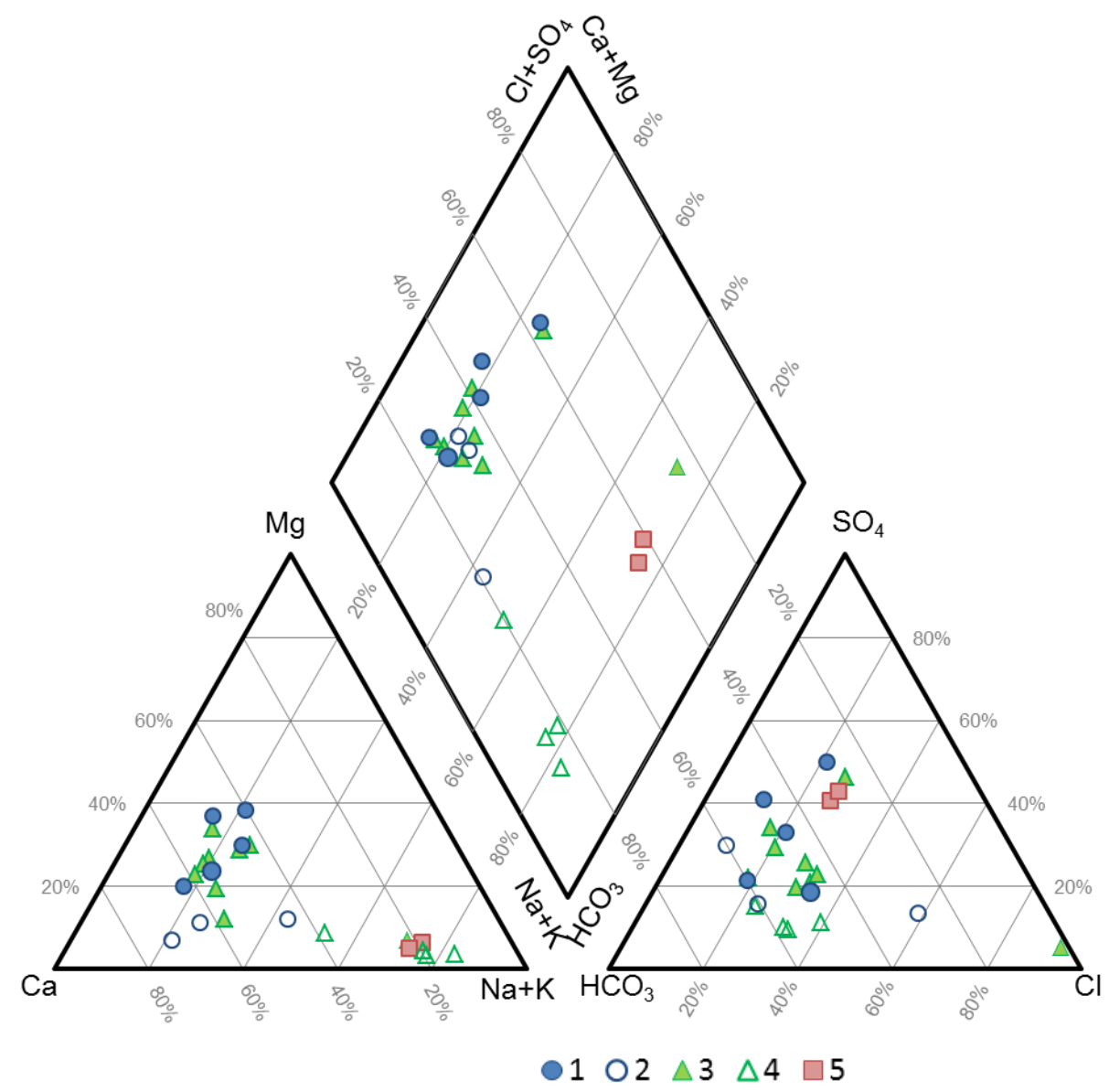

Pис. 2. Диаграмма Пайпера с нанесением данных по химическому составу природных вод водосбораозера Имандра: 1 - подземные воды, приуроченные к холмисто-увалистой равнине; 2 - подземные воды предгорья Хибинского массива; 3 - поверхностные воды, приуроченные к холмисто-увалистой равнине; 4 - поверхностные воды Хибин; 5 - озеро Имандра

Fig. 2. Piper's diagram with the application of natural water chemical composition of the Imandra Lake catchment: 1 groundwater of the hilly plain; 2 - groundwater of Khibiny Massif area; 3 - surface water of the hilly plain; 4 surface water of Khibiny Massif area; 5 - the Imandra Lake

В реках равнинной части рассматриваемой территории формируются нейтральные воды с минерализацией 16-27 мг/дм³. По соотношению анионов воды преимущественно сульфатно-гидрокарбонатные с долей хлорид-ионов - от 5 до 11 \%-экв. Катионный состав рассматриваемых поверхностных вод преимущественно магниево-кальциевый со значительным процентным содержанием натрия (15-22 \%-экв) и содержанием кремния 2,1-2,7 мг/дм³ .

Содержание кремния в поверхностных водах равнинной части исследуемого водосбора соизмеримо с концентрацией кальция и значительно выше концентраций других катионов. Высокая концентрация кремния обнаружена в ручье на территории бывшего КПМ (комплексного мониторингового полигона), где сейчас расположен гостиничный комплекс Тиетта (W-14). Здесь при минерализации вод 27 мг/дм ${ }^{3}$ концентрация кремния составляет 6,4 мг/дм ${ }^{3}$, существенно превышая концентрацию других катионов.

Наименьшие содержании кремния - 0,16 мг/дм ${ }^{3}-$ обнаружены в озере Имандра (W-4) при минерализации 72 мг/дм ${ }^{3}$ и высоких концентрациях сульфат-иона и натрия и в водах озера Дорожное $(\mathrm{W}-2)-1,8$ мг/дм ${ }^{3}$
- при минерализации 30 мг/дм ${ }^{3}$, содержании сульфатиона 9,5 мг/дм ${ }^{3}$ и преобладании кальция и натрия над концентрацией кремния.

В водах озера Дорожное (W-2) при уменьшении $\mathrm{pH}$ 5,99 отмечается некоторое повышение свободной углекислоты - 15,7 мг/дм ${ }^{3}$, что обусловлено процессами минерализации органических веществ $\left(\mathrm{C}_{\text {орг }}=3,82 \mathrm{Mг} /\right.$ дм $\left.^{3}\right)$. В целом концентрация органических веществ в поверхностных водах не превышает 4,6 мг/дм ${ }^{3}$, в отдельных точках концентрация повышается до 12 мг/дм ${ }^{3}$ (W-1 и W-14).

Значительно отличается химический состав вод в точке (W-1), представляющей собой мочажину, рядом с родником «Болотным» (S-16). Минерализация вод составляет $140 \mathrm{мг} /$ дм $^{3}$, а концентрация кремния 7,02 мг/дм ${ }^{3}$, что втрое превышает среднюю минерализацию и концентрацию кремния в поверхностных водах района исследования и в большей степени соответствует составу подземных вод. В водах мочажины отмечено максимальное содержание хлоридиона - 53,5 мг/дм ${ }^{3}$, что составляет почти $70 \%$ от общей суммы содержания анионов в этих водах. 
Таблица 1. Химический состав природных вод водосбора озера Имандра

Table 1. Natural water chemical composition of the Imandra Lake catchment

\begin{tabular}{|c|c|c|c|c|c|c|c|c|c|c|c|c|c|c|c|c|c|c|c|}
\hline \multirow[t]{2}{*}{ № } & $\mathrm{pH}$ & $\mathrm{CO}_{2}$ & $\mathrm{HCO}_{3}^{-}$ & $\mathrm{SO}_{4}{ }^{2-}$ & $\mathrm{Cl}^{-}$ & $\mathrm{Ca}^{2+}$ & $\mathrm{Mg}^{2+}$ & $\mathrm{Na}^{+}$ & $\mathrm{K}^{+}$ & $\begin{array}{l}\text { Мин. } \\
\text { TDS }\end{array}$ & $\mathrm{NO}_{3}$ & $\mathrm{~F}^{-}$ & $\mathrm{Si}$ & $\begin{array}{c}\mathrm{C}_{\mathrm{opr}} \\
\mathrm{DOC}\end{array}$ & $\mathrm{Fe}$ & $\mathrm{Mn}$ & $\mathrm{Al}$ & $\mathrm{Ni}$ & $\mathrm{Cu}$ \\
\hline & & \multicolumn{13}{|c|}{$\mathrm{M \Gamma} / \mathrm{Am}^{3} / \mathrm{mg} / \mathrm{l}$} & \multicolumn{5}{|c|}{ мкг $/$ дм $^{3} / \mu \mathrm{g} / 1$} \\
\hline \multicolumn{20}{|c|}{ Подземные воды/Groundwater } \\
\hline \multicolumn{20}{|c|}{ предгорье Хибинского массива/Khibiny Massif area } \\
\hline S-20 & 7,56 & 3,4 & 62,5 & 9,8 & 10,3 & 22,5 & 1,3 & 7,0 & 1,2 & 115 & 0,07 & $<0,1$ & 4,10 & н.д./n.d. & 19,7 & 0,1 & 10,4 & н.д./n.d. & 0,24 \\
\hline S-21 & 7,38 & 5,5 & 101,3 & 35,7 & 3,0 & 38,6 & 4,2 & 16,5 & 2,0 & 201 & 32,8 & 0,55 & 6,23 & н.д./n.d. & 37,6 & 2,8 & 6,8 & н.д./n.d. & 0,15 \\
\hline S-22 & 7,43 & 3,3 & 67,0 & 10,5 & 2,4 & 12,7 & 2,1 & 11,3 & 5,1 & 111 & 1,95 & $<0,1$ & 6,22 & н.д./n.d. & 0,3 & 0,2 & 8,5 & 0,02 & н.д./n.d \\
\hline \multicolumn{20}{|c|}{ холмисто-увалистая равнина/Hilly plain } \\
\hline S-16 & 6,78 & 12,3 & 29,2 & 13,0 & 2,6 & 7,5 & 4,4 & 3,8 & 1,4 & 62 & 0,44 & $<0,1$ & 8,37 & 1,89 & 6,8 & 0,0 & 9,9 & 0,44 & 0,24 \\
\hline S-17 & 6,54 & 9,1 & 13,3 & 8,0 & 0,8 & 5,5 & 1,1 & 1,6 & 0,3 & 31 & 1,29 & $<0,1$ & 3,70 & 1,82 & 5,8 & 0,1 & 7,8 & 3,44 & 0,19 \\
\hline S-18 & 5,96 & 17,4 & 11,6 & 12,6 & 2,5 & 5,1 & 2,0 & 2,8 & 0,6 & 37 & 1,51 & $<0,1$ & 4,52 & 2,02 & 6,5 & 0,8 & 11,0 & 6,41 & 1,00 \\
\hline S-19 & 6,72 & 9,2 & 37,8 & 7,6 & 2,8 & 10,7 & 2,8 & 3,7 & 2,0 & 67 & 1,09 & $<0,1$ & 4,97 & н.д./n.d. & 0,2 & 0,1 & 7,9 & 0,61 & 0,71 \\
\hline S-23 & 7,07 & 3,5 & 48,7 & 11,1 & 1,9 & 11,1 & 5,2 & 3,4 & 1,1 & 82 & 0,21 & $<0,1$ & 9,58 & 1,67 & 4,7 & 0,1 & 11,5 & 0,58 & 0,28 \\
\hline \multicolumn{20}{|c|}{ Поверхностные воды/Surface water } \\
\hline \multicolumn{20}{|c|}{ Хибинский массив/Khibiny Massif area } \\
\hline W-5 & 7,29 & 3,0 & 17,1 & 1,5 & 0,6 & 0,9 & 0,2 & 5,8 & 1,5 & 27 & $<0,1$ & 0,19 & 2,57 & 1,85 & 13,7 & 0,7 & 80,1 & 0,08 & 0,27 \\
\hline W-7 & 7,14 & 4,4 & 17,1 & 2,5 & 0,6 & 2,7 & 0,4 & 3,8 & 0,9 & 28 & 0,17 & 0,15 & 2,20 & н.д./n.d. & 4,7 & 0,3 & 25,2 & 0,06 & 0,15 \\
\hline W-9 & 7,29 & 3,0 & 16,4 & 1,5 & 0,5 & 1,4 & 0,2 & 5,6 & 1,4 & 27 & 0,1 & 0,17 & 2,92 & 2,09 & 3,7 & \begin{tabular}{|l|}
0,7 \\
\end{tabular} & 42,1 & 0,10 & 0,15 \\
\hline W-11 & 6,91 & 3,5 & 13,9 & 1,5 & 0,7 & 1,2 & 0,1 & 4,9 & 1,1 & 23 & $<0,1$ & 0,20 & 2,87 & 2,17 & 1,7 & 0,2 & 24,9 & 0,06 & 0,04 \\
\hline \multicolumn{20}{|c|}{ холмисто-увалистая равнина/Hilly plain } \\
\hline W-1 & 6,9 & 7,9 & 33,0 & 5,5 & 53,5 & 9,6 & 1,8 & 35,0 & 1,5 & 140 & $<0,1$ & $<0,1$ & 7,02 & 11,4 & \begin{tabular}{|l|}
460,2 \\
\end{tabular} & \begin{tabular}{|l|}
6,1 \\
\end{tabular} & 100,2 & 32,16 & 17,89 \\
\hline W-2 & 5,99 & 15,7 & 9,6 & 9,5 & 2,6 & 3,9 & 1,6 & 2,5 & 0,4 & 30 & $<0,1$ & $<0,1$ & 1,81 & 3,82 & 127,0 & \begin{tabular}{|l|}
3,6 \\
\end{tabular} & 21,3 & 56,93 & 15,67 \\
\hline W-6 & 6,74 & 3,3 & 13,4 & 3,2 & 1,1 & 3,4 & 1,3 & 1,8 & 0,5 & 25 & 0,07 & $<0,1$ & 3,07 & н.д./n.d. & 1,1 & \begin{tabular}{|l|}
3,1 \\
\end{tabular} & 68,0 & 26,86 & 15,19 \\
\hline W-8 & 6,62 & 4,4 & 11,0 & 2,4 & 0,8 & 2,6 & 0,8 & 1,0 & 0,2 & 19 & $<0,02$ & $<0,1$ & 2,19 & н.д./n.d. & 1,5 & \begin{tabular}{|l|}
5,6 \\
\end{tabular} & 134,0 & 5,97 & 5,04 \\
\hline $\mathrm{W}-10$ & 6,27 & 14,0 & 9,5 & 3,4 & 0,7 & 3,1 & 0,9 & 1,0 & 0,3 & 19 & $<0,1$ & $<0,1$ & 2,16 & 4,63 & \begin{tabular}{|l|}
52,6 \\
\end{tabular} & \begin{tabular}{|l|}
9,1 \\
\end{tabular} & 52,9 & 3,83 & 3,86 \\
\hline $\mathrm{W}-12$ & 7,05 & 2,6 & 7,9 & 2,5 & 0,8 & 2,9 & 0,6 & 1,3 & 0,3 & 16 & $<0,1$ & 0,01 & 2,70 & 4,24 & 23,6 & 1,4 & 28,4 & 0,96 & 1,05 \\
\hline W-13 & 6,77 & 5,2 & 16,5 & 7,5 & 1,2 & 5,9 & 1,4 & 2,1 & 0,1 & 35 & $<0,1$ & $<0,1$ & 3,65 & 3,92 & 8,7 & 1,3 & 17,9 & 43,09 & 18,51 \\
\hline W-14 & 6,95 & 5,3 & 13,2 & 3,6 & 1,3 & 4,8 & 0,6 & 2,5 & 0,6 & 27 & $<0,1$ & $<0,1$ & 6,38 & 12 & \begin{tabular}{|l|}
193,9 \\
\end{tabular} & 10,0 & 99,7 & 4,28 & 4,14 \\
\hline W-15 & 6,99 & 4,0 & 13,4 & 3,2 & 0,5 & 3,1 & 1,3 & 1,1 & 0,2 & 23 & 0,1 & $<0,1$ & 2,62 & н.д./n.d. & 0,2 & 1,5 & 32,2 & 2,63 & 1,18 \\
\hline \multicolumn{20}{|c|}{ Озеро Имандра/The Imandra Lake } \\
\hline $\mathrm{W}-3$ & 7,05 & 2,6 & 21,0 & 15,0 & 4,0 & 3,0 & 0,6 & 12,2 & 2,3 & 58 & $<0,1$ & 0,29 & 1,13 & 3,61 & 38,6 & 12,2 & 171,2 & 3,52 & 2,40 \\
\hline W-4 & 7,1 & 5,3 & 23,7 & 19,6 & 5,4 & 4,5 & 0,6 & 15,4 & 2,6 & 72 & $<0,1$ & 0,33 & 0,16 & 4,04 & 27,9 & 13,4 & 32,6 & 4,09 & 2,97 \\
\hline
\end{tabular}

Примечание: н.д. - нет данных.

Note: n.d. - no data.

В поверхностных водах участка с нарушенным лесным ландшафтом (ручей 7 км -W-13) отмечается несколько повышенное содержание сульфат-иона 7,5 мг/дм³. Воды здесь сульфатно-гидрокарбонатные кальциевые с высокой долей магния и натрия (рис. 2).

В водах озера Имандра (W-3, 4) минерализация составляет 58-72 мг/дм ${ }^{3}$, что несколько выше, чем в рассматриваемых поверхностных водах, при этом отмечается почти равное соотношение гидрокарбонат и сульфат-иона. По катионному составу воды здесь натриевые, при уровне кальция в 19-22 \%-экв, а магния и калия $-5-7,5 \%$-экв.

В подземных водах в отличие от поверхностных прослеживается увеличение концентраций кремния, магния, кальция, сульфат-иона и общей минерализации при относительно постоянных концентрациях калия, натрия и хлор-иона (табл. 1).

В поверхностных и в подземных водах содержание кремния соразмерно содержанию кальция, причём значительно превышает концентрации натрия, магния и калия. Подобное поведение обусловлено процессами взаимодействия вод с горными породами на начальных этапах.

В маломинерализованных слабокислых водах складываются благоприятные условия для накопления элементов-гидролизатов [18]. В рассматриваемых водах происходит накопление алюминия, концентрации которого варьируются от 6,8 до 171,2 мкг/дм³ . При этом концентрации железа и марганца невысоки и в среднем составляют 18,4 и 3,2 мкг/дм ${ }^{3}$ соответственно. Наблюдается положительная корреляционная связь между указанными элементами и растворенным органическим веществом, максимальные концентрации этих элементов в водах обнаруживаются в пробах с наибольшим содержанием $\mathrm{C}_{\text {орг }}$. Например, в водах мочажины (W-1) и ручья КМП (W-14), где содержание $\mathrm{C}_{\text {орг }}$ составляет 11,4 и $12 \mathrm{mг} /$ дм $^{3}$, концентрации $\mathrm{Fe}$ достигают 460 и 194 мкг/дм ${ }^{3}, \mathrm{Mn}-6,1$ и 10 мкг/дм ${ }^{3}, \mathrm{Al}-100$ мкг/дм ${ }^{3}$. В водах озера Имандра также отмечено повышенное содержание марганца 12-13 мкг/дм ${ }^{3}$, содержание алюминия достигает 171 мкг/дм ${ }^{3}$ (табл. 1).

В силу особенностей техногенного влияния промышленных предприятий в пределах рассмотренного района концентрации никеля и меди изменяется от 0,02 до 56,93 мкг/дм ${ }^{3}$ и от 0,04 до 18,51 мкг/дм ${ }^{3}$ соответственно. При этом содержание указанных элементов в подземных водах значительно ниже, чем в поверхностных, лишь в отдельных точках отмечаются относительно высокие концентрации. В роднике Дорожный (S-18), расположенном в двух километрах на ЗЮЗ от источника пылегазовых выбросов [15], кон- 
центрации $\mathrm{Cu}$ и $\mathrm{Ni}$ составляют 1 и 6,4 мкг/дм ${ }^{3}$ соответственно, что на порядок превышает таковые в других родниках. Относительно повышенное содержание никеля отмечается и в роднике Горный (S-17) 3,44 мкг/дм ${ }^{3}$, а содержание меди здесь - 0,19 мкг/дм³.

Соотношение содержания некоторых химических элементов в поверхностных $\left(\mathrm{C}_{\text {пов }}\right)$ и подземных водах $\left(\mathrm{C}_{\text {подз }}\right)$ существенно различается для разных частей исследуемой территории (рис. 3). Степень различия может быть связана не только с металлогеническими особенностями, но и с техногенным влиянием комбината «Североникель». Так, например, в пределах хол- мисто-увалистой равнины (западная часть территории водосбора оз. Имандра), подверженной интенсивному воздействию пылегазовых выбросов, в поверхностных водах, по сравнению с содержаниями в подземных, отмечаются более высокие концентрации $\mathrm{Br}, \mathrm{V}$, $\mathrm{Se}, \mathrm{Cd}, \mathrm{Co}, \mathrm{As}, \mathrm{Mn}, \mathrm{Cu}, \mathrm{Fe}$, а в подземных - Sn, Pb, Mo, $\mathrm{Sb}$. Примечательно, что концентрации этих четырёх микрокомпонентов - $\mathrm{Sn}, \mathrm{Pb}, \mathrm{Mo}, \mathrm{Sb}$ - в поверхностных водах в районе Хибинского массива превышают их содержания в подземных водах, а содержание $\mathrm{Br}$, $\mathrm{V}, \mathrm{Se}, \mathrm{Cd}, \mathrm{Co}, \mathrm{As}, \mathrm{Mn}, \mathrm{Cu}, \mathrm{Fe}$ выше в подземных, чем в поверхностных.
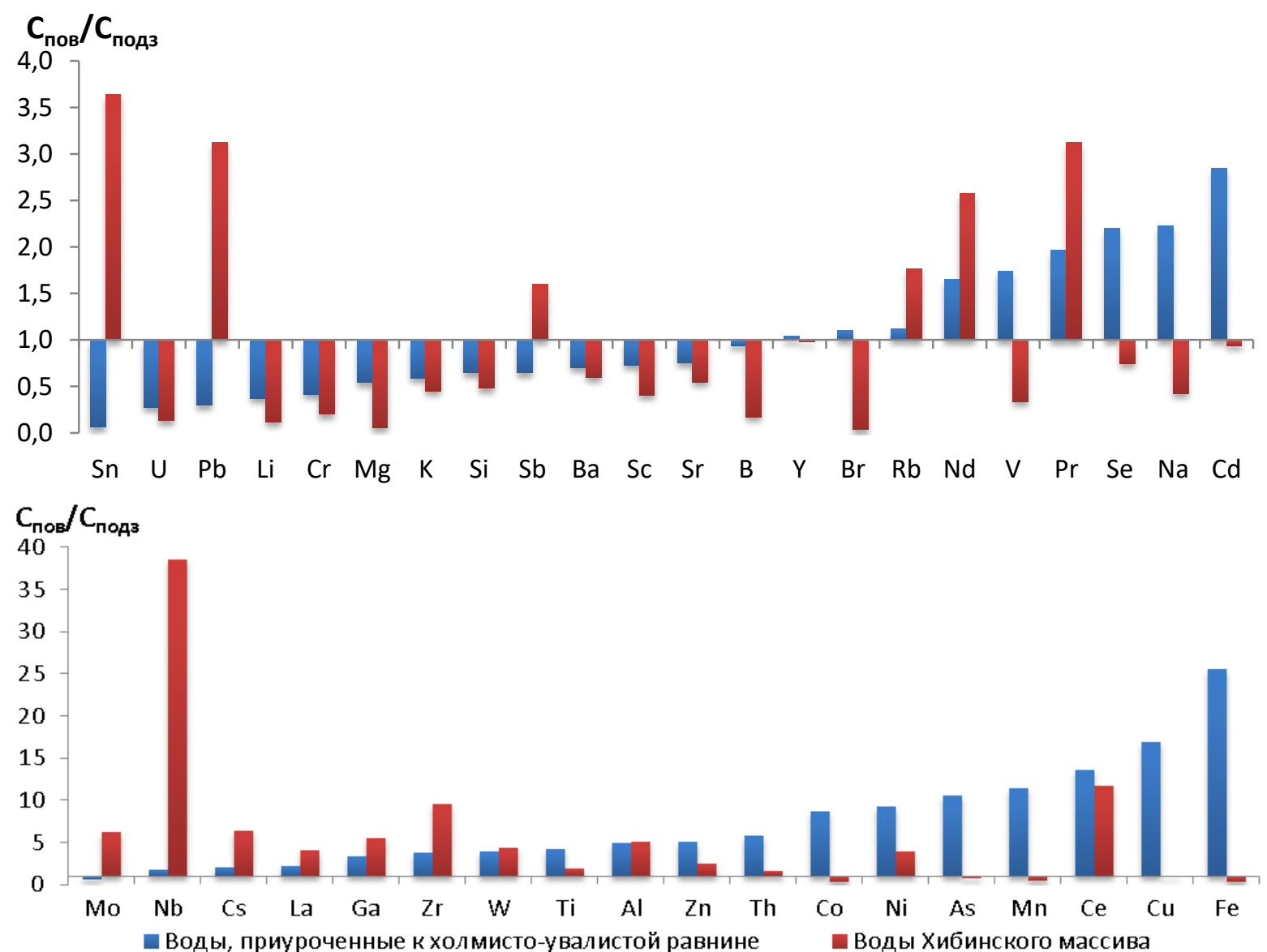

Pис. 3. Отношение содержания химических элементов в поверхностных водах $\left(C_{\text {пов }}\right) \kappa$ содержанию их в подземных водах $\left(C_{\text {подз }}\right)$ для территорий холмисто-увалистой равнины и Хибинского массива

Fig. 3. Ratio of the content of chemical elements in surface waters to their content in groundwater for the hilly plain and Khibiny Massif areas

Дополнительное обогащение вод химическими элементами приводит к смещению состояния их равновесия с некоторыми минералами в сторону вторичной фазы.

Как было показано в работах $[10,11]$, на начальных этапах взаимодействия воды в значительной степени неравновесны с минералами горных пород. Здесь активно протекают процессы растворения первичных минералов, в результате которых максимальное количество элементов переходит в раствор. О резко неравновесном состоянии рассматриваемых вод по отношению к первичным минералам свидетельствует положение точек вне полей устойчивости аль- бита, анортита, мусковита, анальцима, Mg-хлорита (рис. 4).

Согласно оценке степени насыщения вод вторичными минералами рассматриваемые воды не насыщены оксидами и гидроксидами марганца, магния, свинца, кальция - значения индекса насыщения минимальны (порядка $-40 \ldots-10$ ) (табл. 2). При этом значительных отличий в степени насыщенности поверхностных и подземных вод не отмечается. Исключение наблюдается лишь для гидроксида и оксида никеля, индекс насыщения которыми в подземных водах существенно ниже, чем в поверхностных, хотя и находится в отрицательном диапазоне. 
Рассматриваемые воды близки к насыщению оксидами кремния (халцедон, кристобалит), меди (куприт, тенортит, гидроксид двухвалентной меди), а также алюминия (аморфный $\left.\mathrm{Al}(\mathrm{OH})_{3}\right)$.

Воды района насыщены такими гидроксидами, как бемит, диаспор, гиббсит. Не смотря на низкие концентрации железа в рассматриваемых водах, наблюдается их насыщенность соединениями железа: гетитом, гематитом, лепидокрокитом, а также ферригидритом во всех рассматриваемых водах, кроме родника Дорожный (S-18). Наибольшие значения индекса насыщения подземных вод гематитом отмечены в родниках предгорья Хибинского массива (Молодежный S-20, Поддорожный S-21, Прихибинский S-22).

Согласно анализу диаграмм (рис. 4) все рассматриваемые воды насыщены каолинитом и лишь в от- дельных точках отмечается равновесие с $\mathrm{Ca}$ - и $\mathrm{Mg}$ монтмориллонитами и иллитом. Это характерно для родников предгорья Хибин $(\mathrm{S}-20,21,22)$ и родника Спортивный (S-23), расположенного у подножия северо-западного склона горы Поадзуайвенч на окраине г. Мончегорск.

При изучении минерального состава двух почвенных разрезов в районе исследования в изобилии обнаружены аморфные неорганические твердые фазы гели - гидрогётит-гель, гель гидрооксид кремния (опал), нонтронит, гидрослюда и т. д. [19].

Насыщенность рассматриваемых вод вторичными минералами, как и стадия эволюционного развития системы вода-порода, определяется, прежде всего, природными условиями в районе исследования.

Таблица 2. Значения индекса насыщения (SI) вод района озера Имандра вторичными минералами группы оксидов и гидроксидов

Table 2. Index of water saturation (SI) with secondary minerals (group of oxides and hydroxides)

\begin{tabular}{|c|c|c|c|c|c|c|c|}
\hline \multicolumn{2}{|l|}{$\begin{array}{l}\text { Минералы } \\
\text { Minerals }\end{array}$} & \multicolumn{3}{|c|}{$\begin{array}{l}\text { Поверхностные воды } \\
\text { Surface water }\end{array}$} & \multicolumn{3}{|c|}{$\begin{array}{c}\text { Подземные воды } \\
\text { Groundwater }\end{array}$} \\
\hline $\begin{array}{l}\text { Название } \\
\text { Name }\end{array}$ & $\begin{array}{l}\text { Формула } \\
\text { Formula }\end{array}$ & $\begin{array}{l}\text { мин } \\
\text { min }\end{array}$ & $\begin{array}{l}\text { среднее } \\
\text { average }\end{array}$ & $\begin{array}{l}\text { макс } \\
\max \end{array}$ & $\begin{array}{l}\text { мин } \\
\text { min }\end{array}$ & $\begin{array}{l}\text { среднее } \\
\text { average }\end{array}$ & $\begin{array}{l}\text { макс } \\
\max \end{array}$ \\
\hline Сурик/Minium & $\mathrm{Pb}_{3} \mathrm{O}_{4}$ & $-45,17$ & $-40,09$ & $-36,71$ & $-48,02$ & $-42,11$ & $-36,78$ \\
\hline Оксид $\mathrm{Pb} /$ Oxide $\mathrm{Pb}$ & $\mathrm{Pb}_{2} \mathrm{O}_{3}$ & $-35,48$ & $-31,51$ & $-28,98$ & $-37,40$ & $-32,81$ & $-29,40$ \\
\hline Платтнерит/Plattnerite & $\mathrm{PbO}_{2}$ & $-26,83$ & $-23,96$ & $-22,28$ & $-27,82$ & $-24,56$ & $-22,59$ \\
\hline Массикот/Massicot & $\mathrm{PbO}$ & $-10,10$ & $-9,00$ & $-8,15$ & $-11,03$ & $-9,71$ & $-7,79$ \\
\hline Глет/Litharge & $\mathrm{PbO}$ & $-9,90$ & $-8,80$ & $-7,95$ & $-10,83$ & $-9,51$ & $-7,59$ \\
\hline Гидроксид Pb/Hydroxide Pb & $\mathrm{Pb}(\mathrm{OH})_{2}$ & $-5,36$ & $-4,26$ & $-3,41$ & $-6,29$ & $-4,97$ & $-3,05$ \\
\hline Известь/Lime & $\mathrm{CaO}$ & $-24,79$ & $-23,14$ & $-22,54$ & $-24,74$ & $-22,48$ & $-20,93$ \\
\hline Портландит/Portlandite & $\mathrm{Ca}(\mathrm{OH})_{2}$ & $-14,90$ & $-13,24$ & $-12,64$ & $-14,85$ & $-12,59$ & $-11,04$ \\
\hline Гаусманнит/Hausmannite & $\mathrm{Mn}_{3} \mathrm{O} 4$ & $-26,83$ & $-20,30$ & $-16,33$ & $-29,03$ & $-23,33$ & $-16,33$ \\
\hline Биксбиит/Bixbyite & $\mathrm{Mn}_{2} \mathrm{O}_{3}$ & $-20,59$ & $-15,66$ & $-12,86$ & $-22,08$ & $-17,64$ & $-12,67$ \\
\hline Бернессит/Birnessite & $\mathrm{MnO}_{2}$ & $-18,72$ & $-15,37$ & $-13,74$ & $-19,49$ & $-16,30$ & $-13,37$ \\
\hline Пиролюзит/Pyrolusite & $\mathrm{MnO}_{2}$ & $-16,66$ & $-13,31$ & $-11,68$ & $-17,43$ & $-14,24$ & $-11,31$ \\
\hline Манганит/Manganite & $\mathrm{MnOOH}$ & $-10,61$ & $-8,14$ & $-6,74$ & $-11,35$ & $-9,13$ & $-6,65$ \\
\hline Пирохроит/Pyrochroite & $\mathrm{Mn}(\mathrm{OH})_{2}$ & $-10,45$ & $-8,86$ & $-7,69$ & $-11,17$ & $-9,92$ & $-7,88$ \\
\hline Периклаз/Periclase & $\mathrm{MgO}$ & $-13,84$ & $-12,48$ & $-11,93$ & $-13,81$ & $-11,80$ & $-10,73$ \\
\hline Шпинель/Spinel & $\mathrm{MgAl}_{2} \mathrm{O}_{4}$ & $-9,57$ & $-7,90$ & $-6,65$ & $-10,17$ & $-8,87$ & $-8,09$ \\
\hline Брусит/Brucite & $\mathrm{Mg}(\mathrm{OH})_{2}$ & $-9,10$ & $-7,74$ & $-7,19$ & $-9,07$ & $-7,06$ & $-5,99$ \\
\hline Гидроксид Ni/Гидроксид Ni & $\mathrm{Ni}(\mathrm{OH})_{2}$ & $-7,99$ & $-6,53$ & $-5,38$ & $-30,98$ & $-13,19$ & $-6,78$ \\
\hline Бунзенит/Bunsenite & $\mathrm{NiO}$ & $-7,65$ & $-6,18$ & $-5,03$ & $-30,63$ & $-12,84$ & $-6,43$ \\
\hline $\begin{array}{l}\text { Гидроксид Zn (ам) } \\
\text { Hydroxide Zn (am) }\end{array}$ & $\mathrm{Zn}(\mathrm{OH})_{2}$ & $-8,08$ & $-6,68$ & $-5,79$ & $-8,69$ & $-7,19$ & $-6,25$ \\
\hline Гидроксид Zn/Hydroxide Zn & $\mathrm{Zn}(\mathrm{OH})_{2}$ & $-7,80$ & $-6,40$ & $-5,52$ & $-8,41$ & $-6,91$ & $-5,97$ \\
\hline Оксид Zn/Oxide Zn & $\mathrm{ZnO}$ & $-6,79$ & $-5,39$ & $-4,51$ & $-7,40$ & $-5,90$ & $-4,96$ \\
\hline Куприт/Cuprite & $\mathrm{Cu}_{2} \mathrm{O}$ & $-6,30$ & $-3,17$ & $-1,27$ & $-6,95$ & $-5,41$ & $-4,41$ \\
\hline Гидроксид $\mathrm{Cu}^{2+} /$ Hydroxide $\mathrm{Cu}^{2+}$ & $\mathrm{Cu}(\mathrm{OH})_{2}$ & $-4,31$ & $-2,78$ & $-1,87$ & $-4,67$ & $-3,84$ & $-3,06$ \\
\hline Тенорит/Tenorite & $\mathrm{CuO}$ & $-3,28$ & $-1,75$ & $-0,84$ & $-3,64$ & $-2,81$ & $-2,03$ \\
\hline Халцедон/Chalcedony & $\mathrm{SiO}_{2}$ & $-2,00$ & $-0,87$ & $-0,38$ & $-0,66$ & $-0,48$ & $-0,25$ \\
\hline 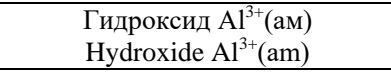 & $\mathrm{Al}(\mathrm{OH})_{3}$ & $-1,32$ & $-0,87$ & $-0,20$ & $-2,14$ & $-1,70$ & $-1,35$ \\
\hline Бемит/Boehmite & $\mathrm{AlOOH}$ & 0,90 & 1,35 & 2,02 & 0,08 & 0,52 & 0,87 \\
\hline Гиббсит/Gibbsite & $\mathrm{Al}(\mathrm{OH})_{3}$ & 1,19 & 1,64 & 2,31 & 0,37 & 0,81 & 1,16 \\
\hline Диаспор/Diaspore & $\mathrm{AlOOH}$ & 2,60 & 3,05 & 3,73 & 1,79 & 2,22 & 2,58 \\
\hline Гидроксид $\mathrm{Fe}^{2+} /$ Hydroxide $\mathrm{Fe}^{2+}$ & $\mathrm{Fe}(\mathrm{OH})_{2}$ & $-8,60$ & $-7,03$ & $-5,32$ & $-8,66$ & $-7,15$ & $-6,24$ \\
\hline Ферригидрит/Ferrihydrite & $\mathrm{Fe}(\mathrm{OH})_{3}$ & $-0,27$ & 1,18 & 2,92 & $-1,36$ & 1,13 & 2,54 \\
\hline Лепидокрокит/Lepidocrocite & $\mathrm{FeOOH}$ & 1,55 & 3,00 & 4,74 & 0,46 & 2,95 & 4,36 \\
\hline Гетит/Goethite & $\mathrm{FeOOH}$ & 2,43 & 3,88 & 5,62 & 1,34 & 3,83 & 5,24 \\
\hline Гематит/Hematite & $\mathrm{Fe}_{2} \mathrm{O}_{3}$ & 7,26 & 10,16 & 13,63 & 5,09 & 10,06 & 12,87 \\
\hline
\end{tabular}



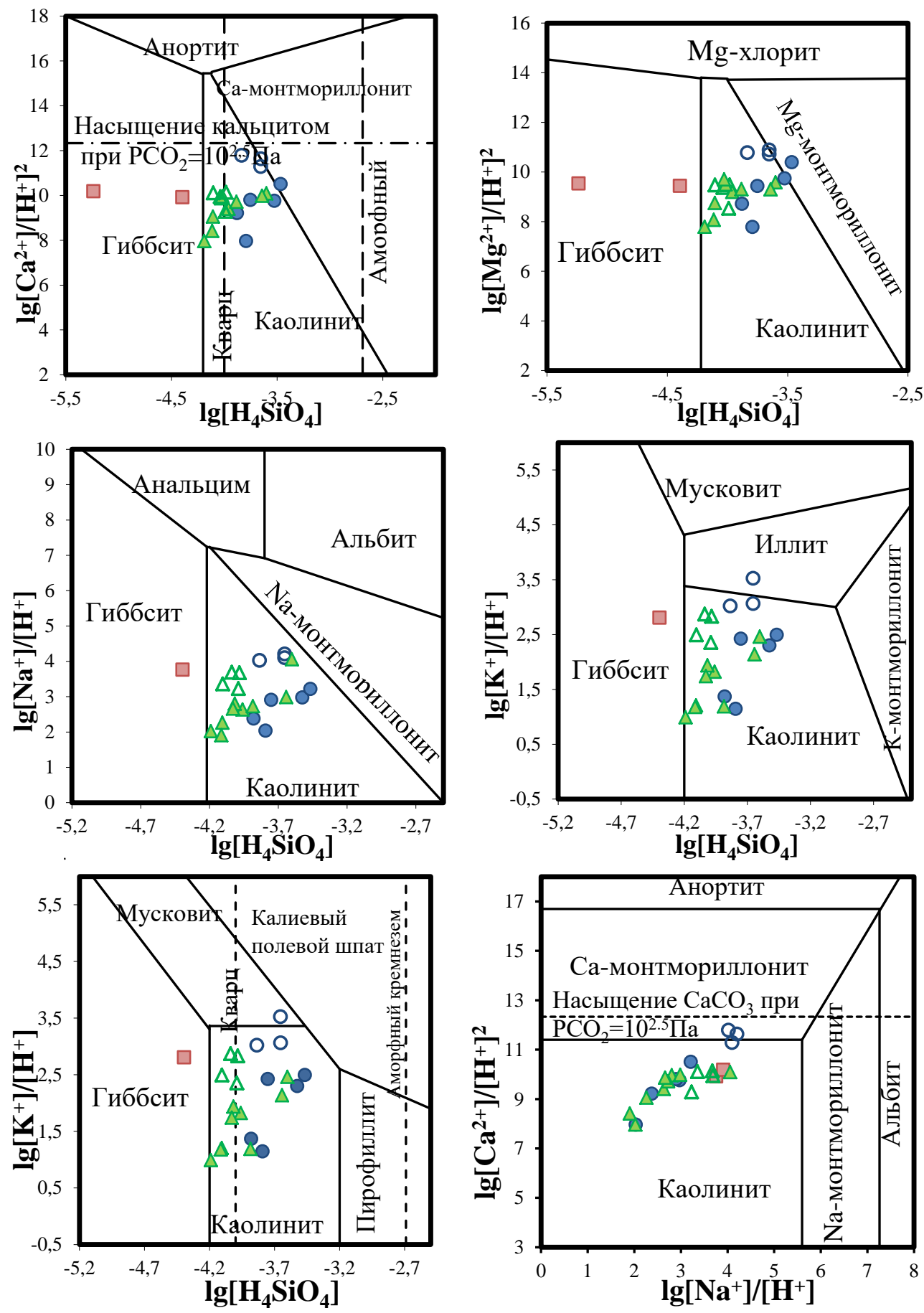

○1 $12 \Delta 3 \Delta 4 \square 5$

Рис. 4. Диаграммы полей устойчивости алюмосиликатных минералов с нанесением данных по химическому составу природных вод водосбора озера Имандра: 1 - подземные воды, приуроченные к холмисто-увалистой равнине; 2 - подземные воды предгорья Хибинского массива; 3 - поверхностные воды, приуроченные к холмистоувалистой равнине; 4 - поверхностные воды Хибин; 5 -озеро Имандра

Fig. 4. Diagrams of aluminosilicate minerals stability fields: 1 - groundwater of the hilly plain; 2 - groundwater of Khibiny Massif area; 3 - surface water of the hilly plain; 4 - surface water of Khibiny Massif area; 5 - The Imandra Lake

Среднегодовое количество осадков довольно значительно и для большей части территории составляет 550-600 мм, иногда достигая 1000 мм и более в горных районах. Средний многолетний подземный сток составляет 3-5 л/(c*км²) [20]. Соответственно, при столь непродолжительном контакте с горными породами происходит формирование ультрапресных подземных вод, находящихся на начальных стадиях взаимодействия в системе вода-порода. 
В водах происходит накопление основных солеобразующих компонентов и кремния, при этом масштабы накопления последнего сопоставимы с масштабами обогащения вод кальцием и превышают масштабы поступления магния и натрия, а отсутствие геохимических барьеров в виде равновесных фаз только способствует этому процессу. Горные породы также являются источником элементов-гидролизатов, однако геохимическая среда рассматриваемых вод не способствует их накоплению в растворе. Указанные элементы являются хорошими комплексообразователями, но низкие концентрации органических кислот в водах не способствуют формированию растворенных органоминеральных комплексов, что приводит к образованию оксидных и гидроксидных соединений.

Насыщенность вод вторичными оксидами и гидроксидами алюминия и железа, так же как и каолинитом, является типичным для рассматриваемых природно-климатических условий. Однако присутствие среди равновесных фаз тенорита и куприта свидетельствует о существовании дополнительного источника поступления меди вследствие техногенного воздействия.

Наличие большого количества равновесных вторичных фаз, представленных оксидами и гидроксидами, а также глинами, способствует активному развитию в водах сорбционных процессов, а также выводу из раствора не только минералообразующих элементов, но и ряда других химических элементов, сорбированных на поверхности вторичных соединений. Этот факт нельзя игнорировать при оценке эколого-геохимического состояния вод и степени антропогенного воздействия на природные воды.

\section{СПИСОК ЛИТЕРАТУРЫ}

1. Skrzypek G., Dogramaci S., Grierson P.F. Geochemical and hydrological processes controlling groundwater salinity of a large inland wetland of northwest Australia // Chemical Geology. 2013. - V. 357. - P. 164-177.

2. The role of anthropogenic and natural factors in shaping the geochemical evolution of groundwater in the Subei Lake basin, Ordos energy base, Northwestern China / F. Liu, X. Song, L. Yang, D. Han, Y. Zhang, Y. Ma, H. Bu // Science of The Total Environment. - 2015. - V. 538. - P. 327-340.

3. Selvakumar S., Chandrasekar N., Kumarb G. Hydrogeochemica characteristics and groundwater contamination in the rapid urban development areas of Coimbatore, India // Water Resources and Industry. - 2017. - V. 17. - P. 26-33.

4. Isotopic and geochemical interpretation of groundwater under the influences of anthropogenic activities / Z. Li, Q. Yang, Y. Yang, H. Ma, H. Wange, J. Luoa, J. Bian, J. D. Martin // Journal of Hydrology. - 2019. - V. 576. - P. 685-697.

5. Li P.Y., Wu J.H. Groundwater environmental problems and thei countermeasures // Journal of Environmental Science and Management. - 2010. - V. 35. - № 4. - P. 60-62.

6. Groundwater geochemistry and microbial community structure in the aquifer transition from volcanic to alluvial areas / S. Amalfitano, A.D. Bon, A. Zoppini, S. Ghergo, S. Fazi, D. Parrone, P. Casella, F. Stano, E. Preziosi // Water Resources. - 2014. V. 65. - P. 384-394.

7. Ammonium threshold values for groundwater quality in the EU may not protect groundwater fauna: evidence from an alluvial aquifer in Italy / T. Di Lorenzo, M. Cifoni, P. Lombardo, B. Fiasca, D.M.P. Galassi // Hydrobiologia. - 2015. - V. 743. - P. 139-150.

8. Marques J.M., Chambel A. $15^{\text {th }}$ Water-Rock Interaction International Symposium, WRI-15. Procedia Earth and Planetary Science. - Evora, Portugal, 2017. - № 17. - P. 980.

\section{Заключение}

Водосборная территория озера Имандра характеризуется распространением преимущественно ультрапресных нейтральных и слабощелочных вод гидрокарбонатного кальциевого состава. Совокупное влияние природных и антропогенных факторов определяет особенности химического состава подземных и поверхностных вод западной и восточной частей водосбора озера Имандра. Специфика вод проявлена в ионном составе, но в большей мере в микрокомпонентном составе. Так, повышенные концентрации никеля и меди в поверхностных водах западной части территории свидетельствует во многом о техногенном влиянии комбината «Североникель».

Все рассматриваемые воды являются неравновесными с первичными алюмосиликатными минералами и находятся в состояния насыщения гидроксидами и оксидами железа и алюминия, в меньшей степени меди, каолинитом и в отдельных точках иллитом, $\mathrm{Ca}$ и $\mathrm{Mg}$-монтмориллонитом. С позиций эволюционного развития система вода-порода в пределах рассматриваемой территории находится на начальных стадиях, что обусловлено в большей степени влиянием природных факторов, а именно высокой интенсивностью водообмена. Однако наличие в составе равновесной минеральной фазы оксидов и гидроксидов меди свидетельствует о значительном влиянии на процессы взаимодействия в системе вода-порода и техногенных факторов.

Исследование выполнено при финансовой поддержке РФФИ в рамках научных проектов № 19-35-90077 и № 18-55-80015.

9. $16^{\text {th }}$ International Symposium on Water-Rock Interaction (WRI-16) and $13^{\text {th }}$ International Symposium on Applied Isotope Geochemistry (1st IAGC International Conference) / O. Chudaev, Y. Kharaka, R. Harmon, R. Millot, O. Shouakar-Stash // E3S Web of Conferences. - Tomsk, Russia, 2019. - V. 98. - P. 1320

10. Геологическая эволюция и самоорганизация системы водапорода: в 5 т. Т. 1: Система вода-порода в земной коре: взаимодействие, кинетика, равновесие и моделирование В.А. Алексеев, Б.Н. Рыженко, С.Л. Шварцев, В.П. Зверев, М.Б. Букаты, М.В. Мироненко, М.В. Чарыкова, О.В. Чудаев. Новосибирск: Изд-во СО РАН, 2005. - 244 с.

11. Геологическая эволюция и самоорганизация системы водапорода: в 5 т. Т. 2: Система вода-порода в условиях зоны гипергенеза / С.Л. Шварцев, Б.Н. Рыженко, В.А. Алексеев, Е.М. Дутова, И.А. Кондратьева, Ю.Г. Копылова, О.Е. Лепокурова. - Новосибирск: Изд-во СО РАН, 2007. -389 с.

12. Евтюгина 3.А., Асминг В.Э. Особенности формирования состава инфильтрационных вод в условиях аэротехногенного загрязнения // Вестник МГТУ: труды Мурманского государственного технического университета. - 2013. - Т. 16. - № 1. C. $73-80$.

13. Dynamics of snowmelt water composition in conifer forests exposed to airborne industrial pollution / V.V. Ershov, N.V. Lukina, M.A. Orlova, N.V. Zukert // Russian Journal of Ecology. - 2016. V. 47. - № 1. - P. 46-52.

14. Геология СССР. Т. 27. Геологическое описание. Мурманская область. - М.: Государственное научно-техническое изд-во литературы по геологии и охране недр, 1958. - 715 с.

15. Ананьев В.Н. Родники Мурманской области: справочник. Мурманск: Книжное изд-во, 2010. - 88 с

16. Chemical composition of natural waters of contaminated area: the case for the Imandra Lake catchment (the Kola Peninsula) / Z.A. Evtyugina, N.V. Guseva, J.G. Kopylova, D.A. Vorobeva // 
IOP Conference Series: Earth and Environmental Science. 2016. - V. 33. - № 1. -012004.

17. Дудкин О.Б., Сандимиров С.С. Геохимические процессы взаимодействия минерального вещества и водной среды в области Хибинского щелочного массива // Геохимия. - 2007. № 11. - С. 1195-1202.

18. Гусева Н.В. Механизмы формирования химического состава природных вод в различных ландшафтно-климатических зонах горно-складчатых областей центральной Евразии: дис. ... д-ра геол.-минерал. наук. - Томск, 2018. - 300 с.

19. Евтюгина 3.А., Копылова Ю.Г., Солдатова Е.А. Минералогический состав почв техногенных пустошей и редколесья //
Экологические проблемы северных регионов и пути их решения: Тезисы докладов VII Всероссийской научной конференции с международным участием, посвященной 30-летию Института проблем промышленной экологии Севера ФИЦ КНЦ РАН и 75-летию со дня рождения доктора биологических наук, профессора В.В. Никонова. - Апатиты, 2019. - С. 19-20.

20. Ресурсы поверхностных вод СССР. Т. 1. Кольский полуостров / под ред. Ю.А. Елкшина, В.В. Куприянова. - Л.: Гидрометеорологическое издательство, 1970 . $-700 \mathrm{c}$.

Поступила 01.12.2019 г.

\section{Информация об авторах}

Гусева Н.B., доктор геолого-минералогических наук, заведующая кафедрой - руководитель отделения геологи на правах кафедры Инженерной школы природных ресурсов Национального исследовательского Томского политехнического университета.

Воробъёва Д.А., инженер-исследователь отделения геологии Инженерной школы природных ресурсов Национального исследовательского Томского политехнического университета.

Eвтюгина 3.A., кандидат биологических наук, доцент Апатитского филиала Мурманского государственного технического университета; научный сотрудник Кольского филиала ФИЦ «Единая геофизическая служба Российской академии наук». 
UDC 556.314(1-924.16)

\title{
FEATURES OF INTERACTION IN THE WATER-ROCK SYSTEM: A CASE STUDY OF THE IMANDRA LAKE CATCHMENT (THE KOLA PENINSULA)
}

\author{
Natalia V. Guseva1, \\ gusevanv@tpu.ru \\ Daria A. Vorobeva ${ }^{1}$, \\ vorobeyda18@gmail.com
}

Zinaida A. Evtyugina2,3, zina_evt@mail.ru

1 National Research Tomsk Polytechnic University, 30, Lenin avenue, Tomsk, 634050, Russia.

2 Apatity branch of «Murmansk State Technical University», 50a, Fersman street, Apatity, 184209, Russia.

3 Kola branch of Geophysical Survey of RAS, 14, Fersman street, Apatity, 184209, Russia.

The relevance of the research is caused by the fact that when assessing the ecological and geochemical state of the natural environment, it is necessary to take into account the ratio of natural and technogenic processes occurring in all its components (soil, water, air, etc.). So, the main natural process that determines the enrichment of water with chemical elements is their interaction with rocks. However, the processes in the water-rock system can be significantly affected by the anthropogenic factor. In this regard, a deep understanding of the characteristics of hydrogeochemical processes within territories subject to significant technogenic impact is an important task of modern ecogeochemistry.

The main aim is to study the water-rock interaction features under technogenic environment conditions in a case of Lake Imandra catchment (the Kola Peninsula).

Objects of the research are natural waters of the Imandra lake catchment (the Kola Peninsula).

Methods. Classical methods of analysis were used to determine the major ion concentration. To determine the trace elements in water, a NexION 300D inductively coupled plasma mass spectrometer was used. Saturation index (SI) was calculated by PHREEQC.

Results. It has been established that within the catchment area of Lake Imandra, low-mineralized natural waters of predominantly hydrocarbonate calcium composition with a neutral and slightly alkaline environment are widespread. The specificity of the chemical composition of the waters of the western and eastern parts of the territory under consideration is determined by the combined influence of natural and anthropogenic factors. Thus, the technogenic impact of the Severonickel plant is confirmed by the increased concentrations of nickel and copper in the surface waters of the western part of the territory. The considered natural waters are not in equilibrium with the primary aluminosilicate minerals and are saturated with hydroxides, iron and aluminum oxides and, to a lesser extent, copper, kaolinite, and, at some points, illite, Ca- and Mg-montmorillonite. From the standpoint of evolutionary development, the high intensity of water exchange in the territory under consideration is a factor that determines the presence of the water-rock system at the initial stages. The presence of copper oxides and hydroxides in the equilibrium mineral phase indicates the influence of technogenic factors on the processes of interaction in the water-rock system.

\section{Key words:}

Hydrogeochemical conditions, chemical composition, natural waters, spring, Imandra lake, Kola Peninsula, water equilibrium, water saturation, saturation index.

The reported study was funded by the RFBR, project number 19-35-90077 and 18-55-80015.

\section{REFERENCES}

1. Skrzypek G., Dogramaci S., Grierson P.F. Geochemical and hydrological processes controlling groundwater salinity of a large inland wetland of northwest Australia. Chemical Geology, 2013, vol. 357, pp. 164-177.

2. Liu F., Song X., Yang L., Han D., Zhang Y., Ma Y., Bu H. The role of anthropogenic and natural factors in shaping the geochemical evolution of groundwater in the Subei Lake basin, Ordos energy base, Northwestern China. Science of The Total Environment, 2015, vol. 538, pp. 327-340.

3. Selvakumar S., Chandrasekar N., Kumarb G. Hydrogeochemical characteristics and groundwater contamination in the rapid urban development areas of Coimbatore, India. Water Resources and Industry, 2017, vol. 17, pp. 26-33.

4. Li Z., Yang Q., Yang Y., Ma H., Wange H., Luoa J., Bian J., Martin J.D. Isotopic and geochemical interpretation of groundwater under the influences of anthropogenic activities. Journal of $H y$ drology, 2019, vol. 576, pp. 685-697.

5. Li P.Y., Wu J.H. Groundwater environmental problems and their countermeasures. Journal of Environmental Science and Management, 2010, vol. 35, no. 4, pp. 60-62.

6. Amalfitano S., Bon A.D., Zoppini A., Ghergo S., Fazi S., Parrone D., Casella P., Stano F., Preziosi E. Groundwater geochemistry and microbial community structure in the aquifer transition from volcanic to alluvial areas. Water Resources, 2014, vol. 65, pp. 384-394.

7. Di Lorenzo T., Cifoni M., Lombardo P., Fiasca B., Galassi D.M.P. Ammonium threshold values for groundwater quality in the EU may not protect groundwater fauna: evidence from an alluvial aquifer in Italy. Hydrobiologia, 2015, vol. 743, pp. 139-150.

8. Marques J.M., Chambel A. $15^{\text {th }}$ Water-Rock Interaction International Symposium, WRI-15. Proc. Earth and Planetary Science. Evora, Portugal, 2017. Vol. 17, pp. 980. 
9. Chudaev O., Kharaka Y., Harmon R., Millot R., Shouakar-Stash O. $16^{\text {th }}$ International Symposium on Water-Rock Interaction (WRI-16) and $13^{\text {th }}$ International Symposium on Applied Isotope Geochemistry (1st IAGC International Conference). E3S Web of Conferences. Tomsk, Russia, 2019. Vol. 98, pp. 1320.

10. Alekseev V.A., Ryzhenko B.N., Shvartsev S.L., Zverev V.P. Bukaty M.B., Mironenko M.V., Charykova M.V., Chudaev O.V. Geologicheskaya evolyutsiya i samoorganizatsiya sistemy vodaporoda: $v 5$ t. T. 1: Sistema voda-poroda v zemnoy kore: vzaimodeystvie, kinetika, ravnovesie i modelirovanie [Geological evolution and self-organization of the water-rock system: in $5 \mathrm{vol}$ Vol. 1: Water-rock system in the earth's crust: interaction, kinetics, equilibrium and modeling]. Novosibirsk, SO RAN Publ., 2005. $244 \mathrm{p}$.

11. Shvartsev S.L., Ryzhenko B.N., Alekseev V.A., Dutova E.M., Kondratieva I.A., Kopylova Y.G., Lepokurova O.E. Geologicheskaya evolyutsiya $i$ samoorganizatsiya sistemy voda-poroda: $v 5$ t. T. 2: Sistema voda-poroda v usloviyakh zony gipergeneza [Geological evolution and self-organization of the water-rock system: in 5 vol. Vol. 2: Water-rock system in a hypergenesis zone]. Novosibirsk, SO RAN Publ., 2007. 389 p.

12. Evtyugina Z.A., Asming V.E. Features of formation of the composition of infiltration water in conditions of aerotechnogenic pollution. Vestnik MGTU, 2013, vol. 16, no. 1, pp. 73-80. In Rus.

13. Ershov V.V., Lukina N.V., Orlova M.A., Zukert N.V. Dynamics of snowmelt water composition in conifer forests exposed to airborne industrial pollution. Russian Journal of Ecology, 2016, vol. 47 , no. 1, pp. 46-52.

14. Geologiya SSSR. T. 27. Geologicheskoe opisanie. Murmanskaya oblast [Geology of the USSR. Vol. 27. Geological description. Murmansk region]. Moscow, State Scientific and Technical Publishing House of Literature on Geology and Mineral Protection, $1958.715 \mathrm{p}$.

15. Ananev V.N. Rodniki Murmanskoy oblasti: spravochnik [Springs of the Murmansk region: a directory]. Murmansk, Murmansk book Publ. house, 2010. 88 p.
16. Evtyugina Z.A., Guseva N.V., Kopylova J.G., Vorobeva D.A. Chemical composition of natural waters of contaminated area: The case for the Imandra Lake catchment (the Kola Peninsula). IOP Conference Series: Earth and Environmental Science, 2016, vol. 33, no. 1, 012004 .

17. Dudkin O.B., Sandimirov S.S. Geochemical processes of interaction of mineral matter and the aquatic environment in the Khibiny alkaline massif. Geohimiya, 2007, no. 11, pp. 1195-1202. In Rus.

18. Guseva N.V. Mekhanizmy formirovaniya khimicheskogo sostava prirodnykh vod $v$ razlichnykh landshaftno-klimaticheskikh zonakh gorno-skladchatykh oblastey tsentralnoy Evrazii. Dis. Dokt. nauk [The mechanisms of the formation of the chemical composition of natural waters in various landscape and climatic zones of mountain-folded areas of central Eurasia. Dr. Diss.]. Tomsk, 2018. $300 \mathrm{p}$.

19. Evtyugina Z.A., Kopylova Y.G., Soldatova E.A. Mineralogicheskiy sostav pochv tekhnogennykh pustoshey i redkolesya [Mineralogical composition of soils of technogenic wastelands and light forests]. Ekologicheskie problemy severnykh regionov i puti $i k h$ resheniya. Tezisy dokladov VII Vserossiyskoy nauchnoy konferentsii s mezhdunarodnym uchastiem, posvyashchennoy 30letiyu Instituta problem promyshlennoy ekologii Severa FIC KNC RAN i 75-letiyu so dnya rozhdeniya doktora biologicheskikh nauk, professora V.V. Nikonova [Ecological problems of the northern regions and ways to solve them. Abstracts of the VII All-Russian scientific conference with international participation dedicated to the $30^{\text {th }}$ anniversary of the Institute of Industrial Ecology of the North Federal Research Center of the Kola Science Center of the Russian Academy of Sciences and the $75^{\text {th }}$ birthday of Dr. of Biological Sc., Professor V.V. Nikonov.]. Apatity, 2019. pp. 19-20.

20. Resursy poverhnostnykh vod SSSR. T. 1. Kolskiy poluostrov [Surface Water Resources of the USSR. Vol. 1. Kola Peninsula]. Ed. by Y.A. Elkshin, V.V. Kupriyanov. Leningrad, Hydrometeoizdat Publ., 1970. $700 \mathrm{p}$.

Received: 1 December 2019.

\section{Information about the authors}

Natalia V. Guseva, Dr. Sc., Head of the Geology Department, National Research Tomsk Polytechnic University.

Daria A. Vorobeva, engineer, National Research Tomsk Polytechnic University.

Zinaida A. Evtyugina, Cand. Sc., associate professor, Apatity branch of «Murmansk State Technical University»; researcher, Kola branch of Geophysical Survey of RAS. 